\title{
Shale Oil \& Gas as an Alternative Source of Energy Management Strategy in Modern Industrial Development
}

\author{
S Karthikeyan', M Vijay Prabhu' ${ }^{2 *}$, Ashutosh Kumar ${ }^{1}$, Sumit Kumar ${ }^{1}$ and Kanhaiya Kumar ${ }^{1}$ \\ ${ }^{1}$ Department of Petroleum Engineering, Excel College of Engg \& Tech, Tamil Nadu, India \\ ${ }^{2}$ Department of Geology, Periyar University, India
}

Received: May 03, 2018; Published: 䟱 May 09, 2018

*Corresponding author: M Vijay Prabhu, Dept of Geology, Periyar University, India

\begin{abstract}
Shale oil \& gas is rapidly emerging as a significant and relatively low cost new unconventional resource in the world. There is potential for shale oil \& gas production to spread globally over the next couple of decades. If it does, it would revolutionise global energy markets, providing greater long term energy security at lower cost for many countries. It is analysed that global shale oil \& gas production has the potential to reach up to 14 million barrels of oil per day by 2035 , this amounts to $12 \%$ of the world's total oil supply. It is estimated that this increase could reduce oil prices in 2035 by around $25 \%-40 \%$ relative to the current baseline EIA projection of $\$ 133 /$ barrel in 2035, which assumes low levels of shale oil \& gas production. In turn, it could increase the level of global GDP in 2035 by around 2.3\%- 3.7\%. However, the benefits of such oil \& gas price reductions will vary significantly by country. Large net oil importers such as India and Japan might see their GDP boosted by around 4\%-7\% by 2035, while the US, China, the Euro zone and the UK might gain by $2 \%-5 \%$ of GDP. Conversely, major oil exporters such as Russia and the Middle East could see a significant worsening of their trade balances by around 4\%-10\% of GDP in the long run if they fail to develop their own shale oil resources. The potential emergence of shale oil presents major strategic opportunities and challenges for the oil and gas industry and for governments worldwide. It could also influence the dynamics of geopolitics as it increases energy independence for many countries and reduces the influence of OPEC. The potential environmental consequences of an increase in shale oil \& gas production are complex and appropriate regulation will be needed to meet local and national environmental concerns. Shale oil \& gas could have adverse environmental effects by making alternative lower carbon transport fuels less attractive, but might also displace production from higher cost and more environmentally sensitive plays.
\end{abstract}

Keywords: Shale oil; Shale gas; Energy Needs; Mapping; Merits; Demerits

Abbreviations: GRF: Green River Formation; TDS: Total Dissolved Solids; ICB: International Competitive Bidding; CBM: Coal Bed Methane; USGS: United States Geological survey; ONGC: Oil and Natural Gas Corporation; OIL: Oil India Ltd

\section{Introduction}

Shale oil \& gas is an unconventional source of oil \& gas produced from shale rock fragments by pyrolysis, hydrogenation, or thermal dissolution. These processes convert the organic matter within the rock (kerogen) into synthetic oil and gas. The resulting oil \& gas can be used immediately as a fuel or upgraded to meet refinery feedstock specifications by adding hydrogen and removing impurities such as sulphur and nitrogen. The refined products of shale is used for the same purposes as those derived from crude oil. The term "shale oil" is also used for crude oil produced from shale's of other very low permeability formations. However, to reduce the risk of confusion of shale oil produced from oil shale with crude oil in oil bearing shales, the term "tight oil" is preferred for the latter. Oil shale was one of the first sources of mineral oil used by humans. The earliest recorded use was in Switzerland and Austria in the early 14th century. In 1596, the personal physician of Frederick I, Duke of Württemberg wrote of its healing properties. Shale oil was used to light the streets of Modena, Italy at the turn of the 17th century. The British Crown granted a patent in 1694 to three persons who had "found a way to extract and make great quantities 
of pitch, tar and oil out of a sort of stone." During the late 19th century, shale oil extraction plants were built in Australia, Brazil and the United States. China, Estonia, New Zealand, South Africa, Spain, Sweden and Switzerland produced shale oil in the early 20th century. The discovery of crude oil in the Middle East during mid century brought most of these industries to a halt, although Estonia and Northeast China maintained their extraction industries into the early 21 st century. In response to rising petroleum costs at the turn of the 21st century, extraction operations have commenced, been explored, or been renewed in the United States, China, Australia and Jordan.

\section{Origin}

The high deposition of shale is found in sedimentary basin, because it is formed from sediments laid down in ancient lakes, seas, and small terrestrial water bodies such as bogs and lagoons. Oil shales deposited in large lake basins, particularly those of tectonic origin, are commonly of considerable thickness in parts. Mineralogically, the deposits are composed of marlstone or argillaceous mudstone, possibly associated with volcanic tuff and evaporate mineral deposits. Major oil shale deposits of this type are the huge Green River Formation (GRF) in the western United States, dating from the Eocene Epoch; oil shales found in the Democratic Republic of the Congo that were laid down in the Triassic Period; and the Albert shale in New Brunswick, Canada, of Mississippian origin. Oil shale deposited in shallow marine environments is thinner than shale of lacustrine origin but of greater areal extent. The mineral fraction is mostly clay and silica, though carbonates also occur. Extensive deposits of black shales of this variety were formed during the Cambrian Period in northern Europe and Siberia; the Silurian Period in North America; the Permian Period in southern Brazil, Uruguay, and Argentina; the Jurassic Period in western Europe; and the Miocene Epoch of the Neogene Period in Italy, Sicily, and California. Oil shale deposited in small lakes, bogs, and lagoons is found associated with coal seams. Deposits of this type occur in a sequence found in western Europe dating from the Permian Period and in deposits of north eastern China laid down in the early Cenozoic Era [1-10].

\section{Properties of shale oil}

The properties of shale vary depending on the deposition of fossils time \& amount of deposition; it also depends on the environmental condition such as temperature, pressure \& rate of depositions, composition of the parent shale and the extraction technology used. Like conventional oil, shale oil is a complex mixture of hydrocarbons, and it is characterized using bulk properties of the oil. Shale oil usually contains large quantities of olefinic and aromatic hydrocarbons. Shale oil can also contain significant quantities of heteroatoms. A typical shale oil composition includes $0.5-1 \%$ of oxygen, $1.5-2 \%$ of nitrogen and $0.15-1 \%$ of sulphur, and some deposits contain more heteroatoms. Mineral particles and metals are often present as well. Generally, the oil is less fluid than crude oil, becoming pourable at temperatures between 24 and $27^{\circ} \mathrm{C}(75$ and $81^{\circ} \mathrm{F}$ ), while conventional crude oil is pourable at temperatures between -60 to $30^{\circ} \mathrm{C}\left(-76\right.$ to $\left.86^{\circ} \mathrm{F}\right)$; this property affects shale oil's ability to be transported in existing pipelines. Before using the shale oil it has to be undergone certain up gradation process. After the up gradation process only the shale oil can be used for the process and usage of shale oil (Figure 1).

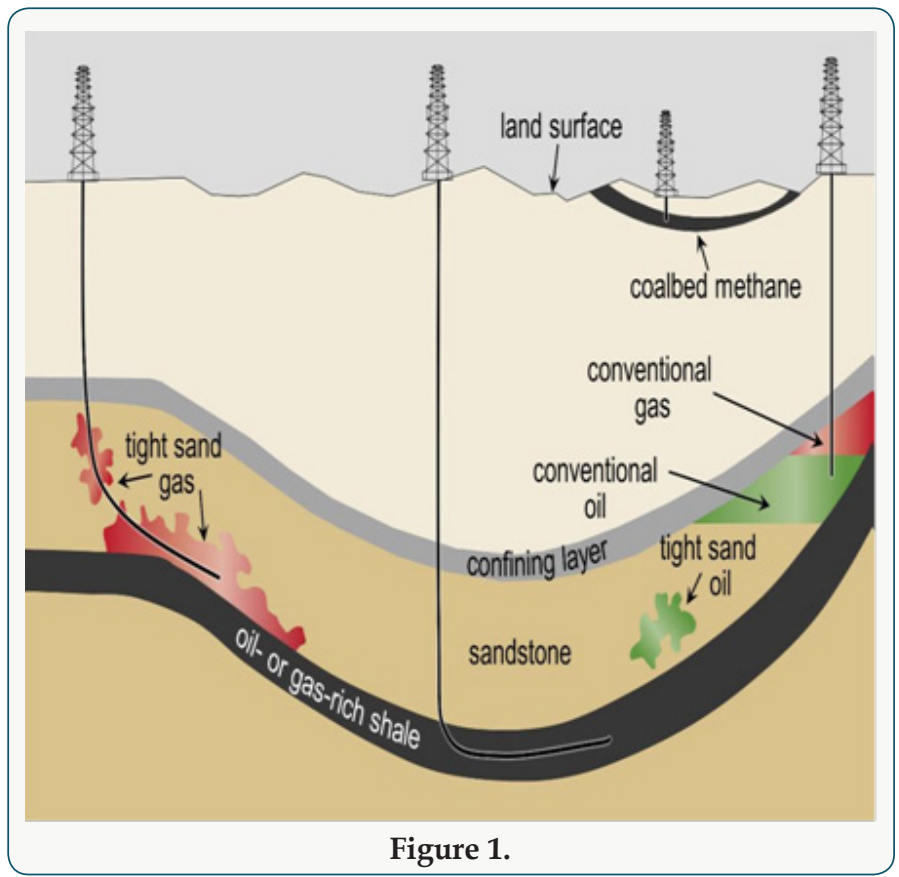

\section{US Shale Revolution}

US companies have unlocked access to rich gas reserves and there is tremendous activity as the country ramps up for full scale production. Shale production is growing vigorously across the country, with existing reserves being put into full production in Pennsylvania, Louisiana and Texas and new reserves being discovered recently for the Marcellus, Eagle, Ford and Utica reserves. Shale gas production has transformed energy market of US, from largest importer to exporter. According EIA the US hold 862tcf of technically recoverable shale gas reserves. Natural gas prices in the US are at record lows as the surge in shale gas production coupled with lower demand has resulted in oversupply and record high gas inventories. The average price of gas at the Henry Hub reduced from US $\$ 8.8$ per mmbtu in 2008 to around US\$2.9 per mmbtu in July 2012. Abundant and assured supplies of cheap gas have led to the expansion of gas based power plants in the country. Since 2008, the wholesale electricity prices has slumped in excess of $50 \%$, resulting in lower electricity costs for domestic and industrial customers. Increase in shale gas operations has created various new job opportunity. The shale gas industry has created employment for approx 6,01,000 people across the value chain, Primarily three factors have come together in the recent past to make shale gas more attractive: 
a) Advancement in horizontal drilling technology.

b) Advancement in hydraulic Fracturing Technology.

c) A surge in the natural gas prices in the past few years as a result of significant demand pressures.

Some of the factors that led to the success of shale gas in the USA can be attributed to favourable geology, large resources play, and persistent R\&D supported by US department of Energy to aid improve recovery techniques. Other factors were deregulated natural gas price, well developed pipeline infrastructure, stable financial authorities or government, easy leasing framework and tax credits [11-23].

\section{Natural Gas in India}

India's natural gas production has been increasing but the demand has been chronically outpacing supply and the country has been net importer from 2004. With the fall of production from KG D6 basin, the gas demands are meet by LNG. In India 4 LNG gas terminals have been developed to deliver the need of gas. The price of gas produced from KG basin under NELP is set at $\$ 4.2 / \mathrm{mmbtu}$ and expected to increase up to $\$ 8.4 / \mathrm{mmbtu}$ by this June under Rangarajan price formulation. While the import price of LNG are as high as $\$ 16 / \mathrm{mmbtu}$. Comparing the price between shale gas and natural gas and the promise shale gas holds in the future, one would expect a flourishing shale gas industry in India. Largely being an oil importing country, India's energy security is pivotal in sustaining its economic growth in the next few decades. As a part of the plan to bridge the energy deficit, India is ready to take its initial steps into shale production.

\section{Shale Gas Prospects in India}

According to estimates by EIA, India has $96 \mathrm{tcf}$ of recoverable shale gas reserves. However there has been a recent downward revision in the estimates. India's shale gas reserve estimates pale in comparison to global standards, however limited exploration has been carried out so far. The Cambay, Krishna, Godavari, Cauvery and the Damodar Valley are the most perspective sedimentary basins for carrying out shale gas activities in the country. The Cambay Basin in Gujarat is the largest basin in the country, spreaded across 20000 gross square miles, with a prospective area of 1940 square miles. Around 20 tcf of gas has been classified as recoverable in this basin. It is estimated that the Krishna Godavari basin, located in eastern India, holds the largest shale gas reserves in the country. It extends over 7800 square miles in gross area with a prospective area of around 4340 sq miles. The basin encloses a series of rich organic materials, containing around 27-30 tcf. In 2011 EIA has assessed risked gas-in-place of $290 \mathrm{TCF}$ with technically recoverable resource of 63 TCF for 4 out of 26 sedimentary basins in India. In view of the advances made by the USA in exploration and recovery of shale oil and gas resources, MoP\&NG has entered into and MOU with the United States Geological survey (USGS). In a study conducted by the USGS in 2011-12, technically recoverable resource of 6.1 TCF has been estimated in 3 out of 26 sedimentary basins in India. The study also indicates potential for shale oil in Indian basins. Further, process of identification of potential shale oil \& gas resources in 11 other basins has also been initiated (Figure 2).

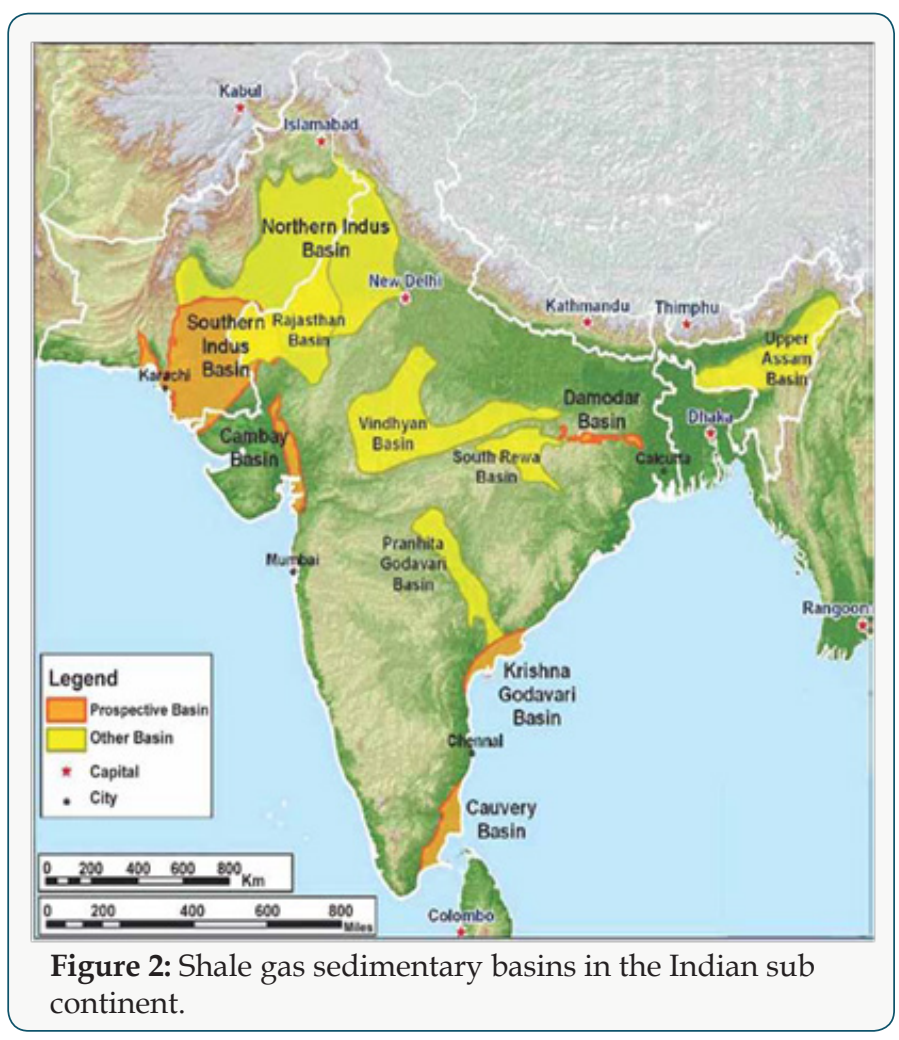

\section{Issues in Exploitation of Shale oil/Gas}

a) Optimal Exploitation of Shale Gas \& Oil requires Horizontal and Multilateral wells and Multistage Hydraulic fracturing treatments of stimulate oil and gas production from shale.

b) This may require large volume of water nearly 3-4 million gallons per well i.e,11000 to 15000 cubic metres of water required for drilling / hydro fracturing depending upon the well type and Shale characteristics.

c) The water after Hydraulic fracturing is flowed back to the surface and may have high content of Total Dissolved Solids (TDS) and other contaminants that typically contain proppant (sand), chemical residue occur in much geologic formation, mainly in shale.

d) Therefore, the treatment of this water before discharge to surface / subsurface water needs to be in line with the Central / State Ground Water Authority regulations.

e) It may contaminate Aquifer both surface \& subsurface from hydro fracturing and fracturing fluid disposal, so there is need for safeguarding the Aquifer.

f) Multiple casing programmes at least 2 casings, will be mandatory, across all sub surface fresh water aquifers. 


\section{Proposed Policy for Shale Gas Exploration}

The policy of the Government of India attracting private investment to move towards self reliance in the indigenous production of oil and gas sector, it is important to have a framework to facilitate and regulate Shale Oil and Gas Exploration and Exploitation. The initial technical study undertaken in the country has indicated presence of Shale Gas as a hydrocarbons resource that can be commercially explored and exploited. The offer of acreages under this policy would be made through an open International Competitive Bidding (ICB) process. The successful bidders would be required to enter into a contract with the Government, which will be negotiated based on the Model Contract (MC). Simultaneous Exploration and Exploitation of Hydrocarbons i.e. conventional Oil and Natural Gas, Coal Bed Methane (CBM), tight gas and Shale Oil and Gas from the same contract area by same/ different operators will be governed by the relevant policy of the Government of India. As such, in case of acreage an offer for shale oil / gas overlaps or falls within an existing Oil and Gas /CBM Block, right of first refusal will be offered to the existing contractor to match the offer of the selected bidder, provided he agrees to al the terms and conditions of the bid. In case they refuse, they will have to enter into a model co development/operating agreement for simultaneous exploration.

All areas which are already allotted under nomination /pre NELP/NELP/CBM rounds and where operations have entered the development \& production phase shall be excluded from area to be offered for shale oil \& gas exploration. As financial and contractual regime for conventional oil and gas and shale oil and gas are different, in case of the same contractor operating both the blocks, the policy will be to adequately ring fence the two so that two distinct accounts are maintained, without affecting each other. All data gathered during the course of operation shall be the property of the GOI. Govt. of India will seek in-principle approval of the State Governments concerned, for the areas of shale oil \& gas blocks, prior to bidding, including facilitation in the matters of land acquisition and water management issues. Fiscal regime proposed for exploration of shale oil / \& gas is proposed to be based on royalty and production linked payments, similar to the regime adopted for CBM operations. Ad valorem Royally at the prevailing rate for crude oil and natural gas would be applicable to shale oil and gas respectively, and accrue to the State Governments, whereas the production liken payment on ad-valorem basis, will be made of the central government. This is proposed to be linked to different production slabs which will be biddable item. This will minimize Government intervention and remove complications in accounting, and incentive for gold plating, which may occur while allowing profit sharing, based on cost recovery. Government share of production will be net of all statutory dues. A Steering Committee will be constituted under the Contract represented by the Government and the contractor which will decide upon the issue on projects \& major work programs, audits and accounts with a view of exploit resources optimally. As shale gas \& oil production is likely to be made in small quantity but over a longer period, it is proposed that the mining lease (ML) may be given for 30 years. Further, extension of ML may be made automatic to all the contractors who do not have any dispute with the State/Central Government, and who do not have any arbitration pending. Offer of blocks would be open to different categories of investors, i.e. public / private sector and domestic /foreigners. Up to $100 \%$ participation by foreign companies and participation through unincorporated Joint Ventures would be permitted.

\section{Current Policy}

The Energy \& Resources cabinet of India has approved a shale gas and oil exploration policy, which will provide a way for state run ONGC and Oil India to hunt for non conventional resources in blocks awarded to them without auction. But, the policy will prevent participation of successful private explorers such as Reliance Industries, GSPC and Cairn India and restrict exploration of shale resources in only five on land basins. The policy also bars exploration of shale oil and gas in 254 blocks, awarded to several public and private sector energy firms in nine rounds under the new exploration licensing policy NELP regime in last 15 years. Even pre NELP blocks such as Cairn operated Rajasthan oilfields and coal bed methane (CBM) blocks are kept out of its preview. Based on this, Oil and Natural Gas Corporation (ONGC) would take up 175 blocks and Oil India Ltd (OIL) another 15 blocks, in three assessment phases. ONGC would get 50 blocks in the first phase, 75 in the second and 50 in the third. OIL would get five blocks each in all three phases. Each assessment phase would be for three years. Companies would get the liberty to select petroleum exploration license or mining lease areas, to be treated as blocks. One pilot well is compulsory in each block during the assessment phase, in every $200 \mathrm{sq} \mathrm{km}$.

\section{Recent Development in Shale}

At Ichhapur in Burdwan, West Bengal ONGC had first struck shale gas in a pilot project. The drilling of Jambusar 55 a well in the Gujarat block, the first well under the pilot programme, started on 27 October 2013 in Cambay Basin by ONGC. As on November 24, the well has been drilled to a depth of 1,735 metres, and further drilling is in progress. The well will cost higher than $\$ 7$ million. ONGC had signed a memorandum of understanding with the ConocoPhillips, US. The two undertook joint

studies of the four basins: Cambay, Krishna Godavari, Cauvery and Damodar. Based on the studies, a shale gas pilot drilling programme was firmed up in the Broach depression area of Cambay Basin in technical collaboration with Conoco. Oil India Ltd and Indian Oil Corporation together snapped up a 30 per cent stake in Houston based Carrizo Oil \& Gas's Niobrara shale gas asset in Colorado for \$85.2 million. While Reliance Industries Ltd (RIL) has a 60 per cent stake in US-based Marcellus' shale play in Carrizo, 
GAIL has a 20 per cent stake in Eagle Ford Shale. Canada is expected to offer Indian upstream companies like ONGC state of art fracking technologies, to develop the vast potential of shale in this country.

\section{Difference between American shale and Indian Shale Revolution}

a) Public acceptance is important and this is the major differentiator between India and USA. Infrastructure and developed gas industry are also key components for success of shale. US have both sufficient infrastructure and developed industry.

b) Another significant component where the India and US differ is that in the US the surface where the mineral is found is owned by individuals or land owners. This proves to be a big incentive for people. Whereas in India, the minerals are owned by government.

c) There is a good availability of data in US because of a long operational history in shale gas E\&P activities of US . India has limited data and would require heavy investments to find the 'sweet spot' although the quality of shale in India is one of the finest in the world; the depth is slightly more which will result in higher cost for the shale gas player, affecting the economics of the play.

d) Availability of land. Land availability is a hurdle due to India's population density and land acquisition will see strong resistance. In US where land availability is not a serious issue and the country has close to 40,000 wells. Availability and management of water resources are likely to be biggest challenges for the shale gas operators. Since fracking requires large amounts of water, availability and then consequently the disposal of contaminated water will be crucial.

\section{Key Benefits of Shale Gas in India}

The state of high demands \& need of energy in India becomes imperative for India to harness all its energy resource, including that of shale oil \& gas. The unlocking of domestic shale oil \& gas can help India meet its growing energy demand, and helping it to reduce its dependence on expensive energy imports. Learning, from shale oil \& gas development in US, India might increase economic activity in the country, thereby boosting government revenues and creating new jobs. Additional gas supplies can also spur investments in downstream segments, which cater to significant latent gas demand in the country. Initially the price of shale gas would not be practicable for power and fertilizer production but it can be utilized for peak loads in power plants, refineries and steel where it can substitute expensive liquid fuels. One of the contribution to shale gas development in the US was the guar gum, exported from India which helps in improving the viscosity and flow of water in the fracking process. The production of guar gum is domestic, will be a great advantage for shale gas development in India. The gum is extracted from guar kiphalli, grown mainly by farmers in arid lands in Rajasthan and Haryana with the serendipitous discovery of its use in shale gas extraction, its production has risen enormously, earning almost US \$ 5 billion during the period from April 2012 to January 2013.

\section{Future Risk involved in Shale Gas}

a) It is quite unknown that when will the price of natural gas will increase is india.

b) If India acquired the necessary technology and expertise to exploit shale gas, it may still fail to treat the resulting waste water.

c) Such a failure may offset any energy gain, But for nation, such as India facing severe water crisis,

Availability of clean water may be more important than access to energy.

d) Lack of Technology.

Policy Needed to be Adopted for creating Shale Revolution in India

\section{Regulatory Policy Support}

a) Need of favourable regulatory framework which will initiate companies to invest in shale activities.

b) A liberal financial authorities or government needs to be implemented for the beneficial of investors.

c) There is need for favourable pricing mechanism for shale operations as this would involve an initial high cost of production than that of conventional oil \& gas.

d) Royalty rate should be reduced in order to promote shale gas operations within India. Companies should receive subsidies for arranging drilling and hydraulic fracturing equipment. There should be Implementation of tax free import of equipment. Moreover,there should be Robustness in land approvals and environment clearances.

\section{Service industry Development:}

a) Inadequate service sector capacity and suitable equipment are the impasse for the development of Shale industry. Shale oil \& gas development requires greater service than the conventional oil \& gas.

b) Need to provide an environment which is responsible for investment in development of high specification equipment required to conduct shale gas operations.

\section{Environmental Issues:}

a) Need to observe \& analysis the environment related problems. 
b) It is necessary to learn the lessons for studies underway on the environmental and public health impact of shale gas development in the US and use them to shape appropriate regulation.

\section{Social Concerns:}

a) To reduce the usage of land, companies must be encouraged to develop super pads in areas where population density is high. The directional drilling system enables the drilling of multiple wells from a single location.

b) It may increase operational costs \& time, but it will reduce the geographical footprint of operations and help win public acceptance. The Indian oil and gas industry is facing a dearth of talent, which could delay projects and impact production. According to Ernst \& Young's estimates, approximately 50\% of the current oil and gas workforce has more than 20 years of experience and the majority of them may retire within the next five to ten years. The attrition levels are high, as $7 \%$ of the current workforce may leave the industry in the next five years. To address these issues, there is a need for significant efforts to attract new talent.

\section{Conclusion}

If the exploration and production of shale oil \& gas in India is continued then it reduce the importing of oil from the other countries. Thus the Indian economic can be waked from the downstream strategy. Thus by exploration of the shale oil \& gas from the Indian basin can lead a fore step to the growth of great nation India. The modern technology would surely yield the growth of shale oil from India. Starting of the shale oil \& gas production in India, it reduces the importing of fuel from other countries with high price. So, our modern technologies in hands with ONGC and geological men's we can hope for the production of fuel and it will enhance the industrial growth. Shale has potential but it is not the silver bullet which will resolve India's energy crisis tomorrow. And although we need a policy around shale, it needs to be holistic and we should incorporate lessons learned from the experiences of other countries (USA and UK) that are further ahead. Understanding the challenges they faced around water, investment incentives, land, etc. will allow us to create a more strong policy for India which will sustain over the long term. Moreover, everyone following the new developments in the Shale industry knows about its importance in the future. Shale is definitely an opportunity; if harnessed effectively, can bring about a change in the energy mix of the country. The effects of shale gas can be far reaching and therefore it needs to be given adequate importance. There are some kinks and considerations that need to be worked out before the shale takes off economically. The industry and the government need to work together to come up with a shale exploration policy that not only encourages foreign investment but also encourages domestic economic growth.

\section{References}

1. Shale gas.

2. Shale oil.

3. http://otisoil-gas.com/oilshaletech.htm

4. Shale Oil and Gas, is India Ready??

5. http://www.naturalgaseurope.com/indian-shale-gas-uniquechallenges-and-solutions-4927

6. http://www.deccanherald.com/content/44366/shale-gas-gamechanger-india.html

7. http://www.dghindia.org/NonConventionalEnergy.aspx?tab=2

8. India takes its first step into shale gas, oil exploration.

9. B Vijay Kumar, Ashutosh Kumar, C Raghavendran, V Akash, A Mohamed Tharik (2017) Shale oil \& gas in India 3(2).

10. Shine Jacob (2013) 3 phase plan for shale gas exploration by ONGC oil.

11.http://articles.economictimes.indiatimes.com/2013-09-25/ news/42362315_1_shale-recourses-conventional-oil-and gasexploration

12. Sujay Mehdudia (2013) shale gas policy- a game changer or spoiler?

13. B Vijay Kumar, Ashutosh Kumar, C Raghavendran, V Akash, A Mohamed Tharik (2017) Shale oil \& gas in India 3(2).

14.http://www.kpmg.com/Global/en / Issues AndInsights / ArticlesPublications/Documents/shale-gas-globalperspective.pdf

15. Jane Nakano, David Pumphrey, Robert Price, Molly A Walton (2012) Prospects for Shale Gas development in Asia.

16. http://www.deloitte.com/assets/Dcom-india/Local\%20Assets/ Documents/ER\%20publications/Shale\%20Gas\%20-

17. Elliot Brennan, Silvia Pastorelli (2013) India's Shale Gas Boom: Dream or Reality?

18. K Biswas, Julian Kirchherr (2013) Shale gas in India: The wrong path?

19. http://www.ey.com/Publication/vwLUAssets/Shale_Gas_-_Key_ considerations_for_India/\$FILE/EYIN1210-084-

20. Shale-gas.pdf

21. Akshaya Ghulati, William Dusek (2013) Is India ready for shale gas.

22. Sachin P Mampatta (2014) Indian cos are looking beyond me CIS countries to meet energy needs: Thomas Milroy.

23. scbhjsaantent/44366/shale-gas-game-change 
(C) (P) This work is licensed under Creative To Submit Your Article Click Here:

Submit Article

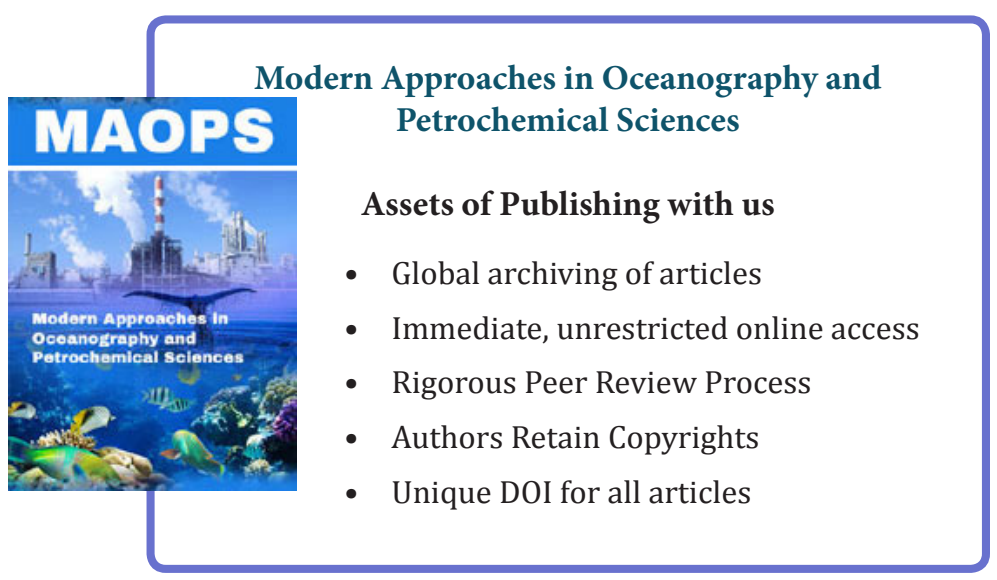

